ПОГРІБНИЙ Д. І.,

кандидат юридичних наук, доцент кафедри господарського права (Наиіональний юридичний університет імені Ярослава Мудрого)

УДК 346.62: 347.731.15

DOI https://doi.org/10.32842/2078-3736-2019-6-1-23

\title{
СУЧАСНІ ТЕНДЕНЦІЇ ВИЗНАЧЕННЯ ПРАВОВОГО СТАТУСУ КРИПТОВАЛЮТ (ГОСПОДАРСЬКО-ПРАВОВИЙ АСПЕКТ)
}

Розглянуто актуальні підходи до визначення правового статусу криптовалют із метою створення дієвих механізмів господарсько-правового забезпечення їх використання в Україні. Проаналізовано процес трансформації наявних підходів до визначення економіко-правової природи криптовалют із боку провідних держав світу та міжнародних фінансових регуляторів. Систематизовано переваги та недоліки використання криптовалют, а також розглянуто генезис такої криптовалюти, як Bitcoin. Зауважено такий необхідний чинник, як співпраця в цифровій сфері між державою, індивідами та колективами в контексті формування парадигми «цифрової взаємозалежності», яка була сформульована у звіті Організації Об’єднаних Націй «Епоха цифрової взаємозалежності». Визначено, що криптовалюта $\epsilon$ новим етапом після появи перших електронних грошей, а також встановлені основні переваги іiі використання, а саме: моментальна швидкість розрахунків (від декількох секунд до декількох хвилин); відсутність комісії за вчинення транзакцій; анонімність розрахунків; незворотність платежів; відсутність необхідності конвертації у валюту країни проведення розрахунків, високий ступінь захищеності операцій. Проаналізовано попередні спроби публічної влади в Україні встановити правовий режим для криптовалютного ринку шляхом ухвалення відповідних нормативно-правових актів у цій сфері. Запропоновано актуальні шляхи оптимізації законодавства щодо легалізації криптовалют в Україні (зокрема, внесення змістовних змін до Господарського та Податкового кодексів, а також до законів: «Про фінансові послуги та державне регулювання ринків фінансових послуг», «Про платіжні системи та переказ коштів в Україні», «Про Національний банк України) з метою створення конкурентних переваг для суб'єктів господарювання та прискорення процесу трансформації української економіки 3 екстенсивного до інноваційного вектора розвитку.

Ключові слова: криптовалюта, правовий статус криптовалют, криптовалютна біржа, віртуальна валюта, електронні громі, иифрова взаємозалежність, блокчейн.

The article discusses current approaches to determining the legal status of cryptocurrencies in order to create effective mechanisms of economic and legal support for their use in Ukraine. Attention is drawn to such a necessary factor as cooperation in the digital sphere between the state, individuals, and groups in the context of the "digital interdependence" paradigm, which was formulated at the Euro Dig 2019 UN Digital Interdependence Report. The process of transformation of existing approaches to defining the economic and legal nature of cryptocurrencies by leading countries and international financial regulators is analyzed. The advantages

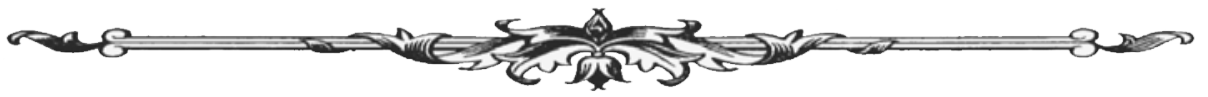


and disadvantages of using cryptocurrencies have been systematized, as well as the genesis of such cryptocurrency as Bitcoin. It is determined that cryptocurrency is a new stage after the first electronic money, as well as the main advantages of its use, namely: instantaneous speed of payments (from a few seconds to several minutes); absence of transaction commission; anonymity of calculations; irreversibility of payments; no need to convert to the currency of the country of production of payments, a high degree of security of operations. It is noted that the potential that can be unlocked by improving digital cooperation is enormous - as are the dangers of failing to create more effective and inclusive ways for civil society, governments, academics and the private sector to work together in this field. The previous attempts of public authorities in Ukraine to establish a legal regime for the cryptocurrency market by adopting relevant regulatory legal acts in this area are analyzed. Actual ways of optimization of the legislation on cryptocurrencies in Ukraine are proposed in order to create competitive advantages for economic entities and accelerate the process of transformation of the Ukrainian economy from an extensive to an innovative vector of development.

Key words: cryptocurrency, virtual currency, electronic money, Bitcoin, legal status of cryptocurrencies, cryptocurrency exchange, digital interdependence, blockchain.

Вступ. У 2019 р. під егідою Організації Об’єднаних Націй (далі - ООН) у Гаазі пройшов форум EuroDig 2019, результатом проведення якого стало створення звіту щодо «цифрової взаємодії» під назвою «Епоха цифрової взаємозалежності» [1]. Термін «цифрова співпраця» уживається в цьому звіті для опису способів спільної роботи з метою максимізації позитивного впливу та мінімізації негативних наслідків IT-технологій, зважаючи на ті соціально-економічні, етичні та правові відносини, які формуються як результат стрімкого розвитку цифрових технологій. Потенціал, який може бути розблокований завдяки поліпшенню цифрової співпраці, величезний, як і небезпеки, якщо людству не вдасться створити більш ефективні та всеосяжні способи спільної роботи громадянського суспільства, урядів, науковців та приватного сектора в цій сфері. Результатом успішної цифрової співпраці має стати таке глобальне середовище, у якому інформаційні технології будуються на фундаменті поваги до прав людини та забезпечують змістовні можливості для всіх людей і країн.

Варто зазначити, що одним із ключових положень вищезгаданого звіту ООН $є$ принцип «включеності», який означає, що «ніхто не повинен залишитися позаду». Публічна політика має будуватися на засадах долучення маргінальних груп до використання цифрових технологій. Ключові елементи такої включеності користувачів - застосування технологій в економічній сфері через а) мобільні гроші; б) цифрову ідентифікацію/авторизацію; в) електронну комерцію. Цифрова взаємодія та цифрові технології повинні у своій основі передбачати дотримання прав людини. Для цього варто визначитися з нормами та межами застосування технологій, щоби захистити приватність користувачів і убезпечити їх [2]. Отже, визначення правового статусу криптовалют і створення дієвих господарсько-правових механізмів їх використання стане одним з індикаторів суттєвого оздоровлення економіки України.

Питанням, присвяченим визначенню правового статусу та природи такого феномену, як криптовалюти, приділялася велика увага 3 боку таких іноземних і вітчизняних правників та економістів, як: А. Грінспен (А. Greenspan), Б. Кінг (B. King), Е. Мак (Е. Мас), Р. Коен (R. Coen), K. Скінер (C. Skinner), Д. Вахрушев (D. Vahrushev), K. Пащенко (K. Pashchenko), O. Железов (O. Zhelezov), Н. Поливка (N. Polyvka) та інші. Проте ці питання потребують подальшого ретельного опрацювання.

Постановка завдання. Метою статті $\epsilon$ аналіз актуальних підходів до визначення правового статусу та природи такого феномену, як криптовалюти, з метою створення дієвих механізмів господарсько-правового забезпечення їх використання.

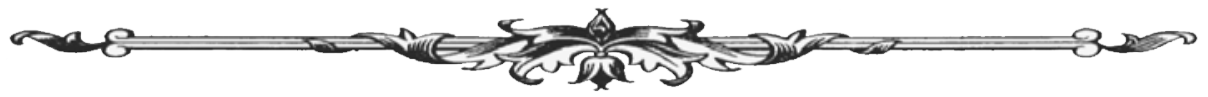


Результати дослідження. Одним із провідних векторів на шляху трансформації української економіки $€$ впровадження сучасних інформаційних технологій, зокрема використання криптовалют і електронних грошей у господарському обороті. Варто зазначити, що зростання популярності криптовалют у світі відбувається на тлі відсутності єдиного розуміння поняття «криптовалюта» (“cryptocurrency”) - воно варіюється від ототожнення 3 поняттями «товар», «платіжний засіб», «розрахункова одиниця» до понять «нематеріальний цифровий актив», «інвестиційний актив», «фінансовий актив», «окремий вид цінних паперів» тощо. Криптовалюта, у цьому сенсі, $€$ новим етапом після появи перших електронних грошей. Вона може задовольнити такі сучасні зростаючі вимоги, як: моментальна швидкість розрахунків (від декількох секунддо декількох хвилин); відсутність комісії за вчинення транзакцій; анонімність розрахунків; високий ступінь захищеності операцій; незворотність платежів; відсутність необхідності конвертації у валюту країни проведення розрахунків) [3, с. 104].

Термін «криптовалюта» часто ототожнюють із поняттями «віртуальна валюта» (“virtual currency”) та «цифрова валюта» (“digital currency”). Однак ці терміни не можна вважати абсолютними синонімами криптовалюти, оскільки вони ширші за обсягом («криптовалюти» є одним із видів «децентралізованих віртуальних валют» - доповідь FATF (Міжнародна група 3 протидії відмиванню брудних грошей) «Віртуальні валюти», 2014 р.) [4]. Наприклад, Свропейський центральний банк у своїх дослідженнях про віртуальні цифрові валюти "Virtual currency schemes - a further analysis" не висловлює однозначного рішення щодо використання віртуальних валют, застерігає від їх використання у своїй фінансовій діяльності [5].

Визначення поняття «віртуальна валюта» закріплено в Директиві СС 2018/843 Свропейського парламенту та Ради від 30 травня 2018 р. У цьому документі зазначений термін визначається так: «віртуальні валюти» - цифрове представлення вартості, яке не видається або не гарантується центральним банком або державним органом, не обов'язково приєднується до законодавчо встановленої валюти і не має юридичного статусу валюти чи грошей, але приймається фізичними та юридичними особами як засіб обміну, може передаватися, зберігатися та торгуватися в електронному вигляді [6].

Варто погодитись із тією думкою, що феномен появи Bitcoin не був очевидним і прогнозованим для економістів та правників, незважаючи на те, що ця перша повноцінна криптовалюта мала деякі попередні прототипи та розробки. Так, перші криптографічні протоколи електронної готівки були запропоновані ще в 1983 р. Девідом Чомом (David Chaum) i Стефаном Брендсом (Stefan Brands) [7]. Зазначені науковці планували розробити систему, що дає змогу поєднати анонімність платежів із прозорістю для всіх учасників ринку. Був запропонований так званий «сліпий підпис», що давав можливість провести секретну угоду між двома анонімними користувачами, але водночас повідомити про сам факт ії здійснення стороннім спостерігачам. Результатом стала розробка протоколу «електронної готівки» (“digital cash”).

Значно пізніше, у 2008 р., людиною або групою людей під псевдонімом Сатоші Накомото створено концепцію Bitcoin, а у 2009 р. опубліковано принцип роботи платіжної системи у вигляді розподіленої, децентралізованої пірингової мережі, або р2p (від англ. peerto-peer - від партнера до партнера). Отже, Bitcoin встиг пройти еволюцію від віртуальної валюти для комп'ютерних ігор до криптовалюти, яка конкурує з доларом Сполучених Штатів Америки (далі - США). Зокрема, кількість компаній, які приймають Bitcoin як оплату за товари та послуги, постійно зростає. Станом на 4 листопада 2019 р. ринкова капіталізація криптовалюти Bitcoin становить приблизно 167 млрд доларів США [8]. Порівняльний аналіз курсу криптовалюти Bitcoin та золота свідчить про те, що вже в середині 2013 р. вони наблизились настільки, що дозволило говорити про Bitcoin як про «електронне золото». У грудні 2017 р. ця криптовалюта стала шостою за капіталізацією валютою світу, обійшовши рубль, англійський фунт і південнокорейську вону.

Варто зазначити, що основою Bitcoin $\epsilon$ технологія блокчейн (від англ. blockchain-ланцюжокблоків).Блокчейн-цепублічнабазавсіхтранзакцій,коли-небудьзроблених

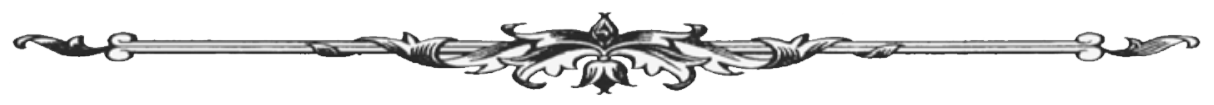


у системі Bitcoin, яка організована в систему блоків даних. Кожний новостворений блок містить хеш-суму (контрольну суму) попереднього. Отже, створюється безперервний ланцюжок взаємопов’язаних блоків інформації, який бере початок від так званого genesis block (перший блок у системі Bitcoin) до останнього, знайденого системою блока. Використовуючи цю базу, кожен користувач має змогу дізнатися, яка кількість Bitcoin належала конкретному гаманцю в певний відрізок часу. Блокчейн зберігається одночасно у всіх користувачів мережі.

Специфічною ознакою $є$ те, що Bitcoin не має єдиного емісійного центру, а емісія відбувається автоматично на основі математичного алгоритму, і кожен учасник мережі бере участь у підтриманні їі роботи. Транзакції із цифровим підписом між двома вузлами передаються до всіх вузлів мережі p2p, а самі дані про переміщення коштів зберігаються в розподіленій базі даних. Для запобігання можливості трати чужих грошей або використання своїх коштів двічі використовуються криптографічні методи захисту інформації [9, с. 4].

Варто зауважити, що до недоліків використання криптовалют передусім належать ризики, пов'язані з відсутністю їх реального забезпечення. Отже, за настання форс-мажорних обставин (нові економічні кризи, війни, заборони й обмеження використання на рівні держав) вартість криптовалют на фондовому ринку може миттєво перетворитись із ліквідного активу на «мильну бульбашку». До переваг варто віднести такі чинники, як: моментальна швидкість розрахунків (від декількох секунд до декількох хвилин); відсутність комісії за вчинення транзакцій; анонімність розрахунків; високий ступінь захищеності операцій; незворотність платежів; відсутність необхідності конвертації у валюту країни проведення розрахунків.

Сьогодні налічується вже більше тисячі видів криптовалют, серед яких найбільш поширені такі, як Bitcoin, BitcoinCash, Ripple, Ethereum, Tether, Litecoin та інші. Позиція урядів різних країн стосовно визначення статусу криптовалют із плином часу суттєво змінювалася, і цей процес зберігає свою динаміку. Варто зазначити, що розвинуті країни Азії (Китай, Корея, Японія) займають великий сегмент на світовому ринку криптовалют.

Так, Китай поетапно змінював свою політику щодо криптовалют від поблажливого ставлення як до «пустушок з Інтернету» до повної заборони їх обігу на території країни. Проте Китай і в цьому плані перебуває «у форватері» розвитку інформаційних технологій. Китайська Народна Республіка готується до запуску власної криптовалюти, що підтримується державою, видаляючи повідомлення в Інтернеті, які стверджують, що технологія blockchain (блокчейн) - це афера. У Китаї ухвалений новий закон, який набуває чинності 1 січня наступного року, спрямований на «сприяння розвитку криптографічного бізнесу й убезпечення кіберпростору й інформації» [10].

Інша провідна держава Східної Азії, а саме Корея, також має намір надати правовий статус криптовалютам, щоб залишатися на передовій інновацій у цьому секторі. Корейський президентський комітет із четвертої промислової революції підкреслив важливість технологіï blockchain у майбутній 4-й промисловій революції ${ }^{1}$, зазначивши, що уряд Кореї повинен удосконалити регуляторні процедури для кращої підтримки стартапів, що сприяють інноваціям, включаючи ті, що розробляють криптовалюти [11].

Японія $є$ першою країною, яка визнала криптовалюту в рамках правової системи та забезпечила законний спосіб для своїх громадян користуватися криптовалютами. Станом на березень 2018 р. у країні було понад 3,5 млн осіб, які активно використовують і торгують криптовалютами. Із 2016 р. ця країна офіційно визнала криптовалюту як вид грошей для здійснення платежів. Законопроєкт, представлений в японському парламенті в березні 2016 р., стосувався фінансових технологій і конкретно назвав віртуальну валюту частиною цього напряму. У результаті такого офіційного визнання ринок криптовалют перейшов до компетенції Агенції фінансових послуг Японії - FSA. Ця Агенція регулює всі банківські й інвестиційні ресурси у країні. FSA як легітимізує криптовалюту, так і встановлює стандарти для роботи криптовалютних бірж [12].

Четверта промислова революція - це сучасне та розвиваюче середовище, у якому такі технологі та тенденції, як Інтернет речей (IoT), робототехніка, віртуальна реальність (VR) та штучний інтелект (AI) змінюють спосіб нашого життя та роботи.

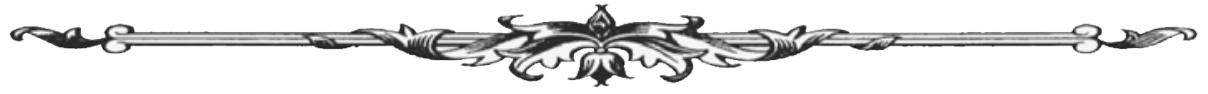


Досить активна дискусія щодо нормативного регулювання криптовалют точиться у Великобританії. До цього часу Великобританія не ухвалила жодного конкретного закону, орієнтованого на криптовалюти, і їі фінансові регулятори мали досить поблажливий підхід до їх обігу. Хоча у країні немає чіткого законодавства про криптовалюти, вони не вважаються законним платіжним засобом, тоді як біржі потребують реєстрації у FCA (Financial Conduct Authority). Керівництво FCA підкреслює, що суб'єкти, які займаються криптовалютною діяльністю, підпадають під діючий фінансовий регламент щодо деривативів (наприклад, ф'ючерси й опціони) та потребують авторизації. Але у 2019 р. FCА опублікувало Посібник (PS19/22), яким класифікувало різні види криптоактивів [13]. Ураховуючи те, що Великобританія вже не змогла зберегти своє глобальне лідерство в галузі фінансів, потенційна відмова від легалізації криптовалют стала би серйозним викликом. Адже навіть Китай, який раніше був однією з найбільш ворожих до криптовалют країн, ухвалив свій перший «криптозакон», який набуде чинності в січні 2020 р. [14].

У деяких розвинутих державах (Швейцарія, Канада, Австралія) криптовалюти включені до офіційних котирувань на фондових біржах. Наприклад, у США вже сформувалась прецедентна практика, яка визначає криптовалюти як «валюту, або ж іншу форму грошей». Позиція американських суддів була підтверджена і Financial Crimes Enforcement Network (FinCEN), яка у 2013 р. кваліфікувала Bitcoin як «одну з форм грошей». Проте інший впливовий американський орган Internal Revenue Service (IRS) визначив, що для цілей федерального оподаткування криптовалюту слід трактувати не як «форму грошей», а як власність. У Німеччині Bitcoin має статус «приватних коштів». The German Federal Financial Supervisory Authority (BaFin) визначає його як приватні кошти, які використовуються для оплати і замінюють традиційну валюту в цивільно-правових договорах [15].

В Об'єднаних Арабських Еміратах (далі - ОАЕ) Комісія з регулюванням фондового та товарного ринків (SCA) розмістила інформацію про те, що розроблені «правила щодо криптографічних активів». Зазначається, що цей проєкт охоплює всі аспекти індустрії криптовалют в ОАЕ, включаючи необхідні вимоги до емітента токенів, політику безпеки та зберігання, а також заходи для захисту інвесторів, інформаційну безпеку [16]. За законодавством Ізраїлю Bitcoin не підпадає під юридичне визначення валюти ні як фінансове забезпечення, ні як оподатковуваний актив. Цікаво, що в Канаді та Новій Зеландії дозволено отримувати цифрову заробітну плату.

За експертними оцінками розмір сегмента майнінга криптовалют в Україні сягає 100 млн доларів США і більше на рік, обсяг ICO/ITO компаній з українським походженням чи розміщенням команд розробників у 2017-2018 рр. - приблизно 100 млн доларів США [17]. В Україні справжня популярність криптовалют розпочалася у 2014 р., коли ентузіастами було створено громадську організацію, що має на меті поширення, розвиток і вивчення Bitcoin та інших віртуальних валют на території нашої держави - Bitcoin Foundation Ukraine (BFU). У 2014 р. з'являється і перша реакція Національного банку України (далі - НБУ): 10 листопада 2014 р. опубліковане роз'яснення НБУ «Щодо правомірності використання в Україні «віртуальної валюти/криптовалюти» Bitcoin”. У цьому нормативному документі Bitcoin визначається як «грошовий сурогат, який не має забезпечення реальною вартістю і не може використовуватися фізичними та юридичними особами на території України як засіб платежу, оскільки це суперечить нормам українського законодавства» [18].

Починаючи із грудня 2016 р. Українська біржа запустила торгівлю ф'ючерсними контрактами на індекс Bitcoin. Специфікація контрактів зареєстрована у НКЦПФР. Це фактично перший регульований ринок у світі, який запропонував ф'ючерсні контракти на Bitcoin. У 2016 р. НБУ схвалив дорожню карту “Cashless economy”, у якій ідеться про наміри впровадження технології блокчейн в Україні. Зокрема заплановано перевести деякі державні реєстри на цю інноваційну технологію [19].

У прес-релізі від 30 листопада 2017 р., що має назву «Спільна заява фінансових регуляторів щодо статусу криптовалют в Україні», узагальнюється позиція Національного банку України, Національної комісії з цінних паперів та фондового ринку і Національної

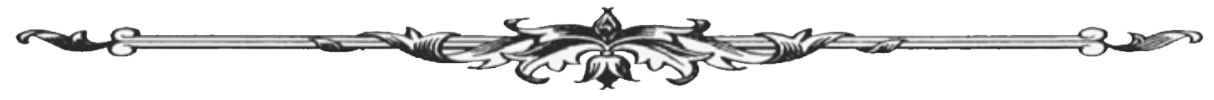


комісії, що здійснює регулювання у сфері ринків фінансових послуг, щодоо правового статусу криптовалют. Позиція фінансових регуляторів зводиться до того, що, незважаючи на існування у світі численних практик використання криптовалют як міри вартості, засобу обміну та накопичення, їхня складна правова природа не дозволяє ототожнити їх із будьяким із суміжних понять (грошові кошти, валюта, валютна цінність, законний платіжний засіб, електронні гроші, цінні папери, грошовий сурогат тощо) [20].

У жовтні 2019 р. вийшов прес-реліз новоствореного Міністерства цифрової трансформації, відповідно до якого урядом України планується напрацювати варіанти оподаткування у сфері поводження із криптовалютами, а до літа 2020 р. затвердити міжнародні рекомендації щодо боротьби з відмиванням коштів для того, щоби мінімізувати негативні наслідки легалізації криптовалют. Цей процес матиме на меті підвищення конкурентоспроможності України на світовому ринку віртуальних активів і, зокрема, передбачає легалізацію майнінга криптовалют, а також залучення іноземних інвесторів та міжнародних криптовалютних бірж до України [21].

До речі, ідея визначення правового статусу криптовалют не $є$ революційною для публічної влади в Україні. Так, проєкт Концепції державної політики у сфері віртуальних активів був оприлюднений для обговорення колишнім урядом 25 жовтня 2018 р. Концептуальні тези цієї Концепції такі: а) чітке визначення правового статусу віртуальних валют і діяльності у сфері віртуальних валют; б) визнання суб' єктів господарювання, що надають послуги з обміну віртуальних валют на фіатні валюти і навпаки, суб'єктами первинного фінансового моніторингу; в) моніторинг, аналіз проблем і тенденцій розвитку ринку віртуальних активів і віртуальних валют із метою вироблення пропозицій щодо вдосконалення регуляторної політики; г) визначення понять «віртуальна валюта», «майнінг», «ICO/ITO», «смарт-контракт» [22].

Спробою врегулювання у правовому полі відносин у сфері обігу, використання, зберігання та проведення операцій за допомогою криптовалюти став проєкт закону України «Про обіг криптовалюти в Україні» № 7183 від 6 жовтня 2017 р. [23] і альтернативний законопроєкт «Про стимулювання ринку криптовалют та їх похідних в Україні» № 718-1 від 10 жовтня 2017 р. [24]. Але станом на 29 серпня 2019 р. обидва законопроєкти були відкликані Верховною Радою.

Висновки. Варто погодитись із тією позицією, що для розвитку електронної комерції в Україні необхідно внесення змін до законодавства і надання можливості здійснювати платежі не лише гривнею, а й криптовалютою, як для суб'єктів господарювання, так і для негосподарюючих суб'єктів. Так, на даному етапі більш раціональним у процесі створення фундаментальної нормативної бази для господарсько-правового забезпечення використання Bitcoin та інших криптовалют в Україні вбачається внесення змістовних змін до чинних нормативно-правових актів у цій сфері, зокрема до Господарського та Податкового кодексів, а також до законів: «Про фінансові послуги та державне регулювання ринків фінансових послуг», «Про платіжні системи та переказ коштів в Україні», «Про Національний банк України». Такі нормативні зміни мають вирішити деякі проблеми щодо обігу, зберігання, володіння та використання криптовалют у правовому полі, які існують не лише в Україні, але і в багатьох інших країнах, зокрема: а) невизначеність правового статусу криптовалют; б) відсутність методики обліку операцій із криптовалютами; 3) неврегульованість бази оподаткування.

Отже, створення належних господарсько-правових механізмів регулювання обігу криптовалют і діяльності криптовалютних бірж стане запорукою успішної інтеграції української економіки в міжнародне інноваційне середовище. Водночас варто враховувати потенційні переваги та недоліки використання криптовалют як платіжного засобу. Міжнародний досвід щодо сфери віртуальних активів і віртуальних валют є розрізненим, більшість країн поки не визначилися із правовим статусом віртуальних валют. Загальною тенденцією $є$ те, що держави намагаються виійти із ситуації правової невизначеності.

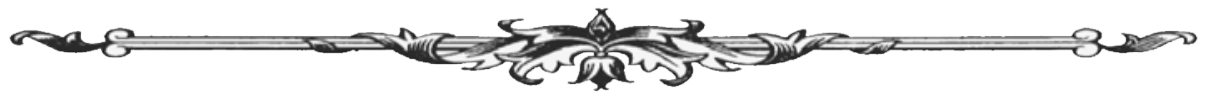




\section{Список використаних джерел:}

1. The age of digital interdependence. Report of the UN Secretary-General's High-level Panel on Digital Cooperation. URL: https://www.un.org/en/pdfs/DigitalCooperation-reportfor\%20web.pdf (дата звернення: 06.11.2019).

2. Звіт ООН щодо Інтернету та технологій: виклики й благо для суспільства. Профспілка праиівників освіти і науки України : вебсайт. URL: https://pon.org.ua/novyny/7202-zvt-oon-schodonternetu-ta-tehnology-vikliki-y-blago-dlya-susplstva.html (дата звернення: 06.11.2019).

3. Погрібний Д. Перспективи визначення правового статусу криптовалют в Україні (господарсько-правовий аспект). Вісник Харківського національного університету імені В.Н. Каразіна. Серія «Право». 2018. № 26. С. 104-107.

4. Отчет FATF «Виртуальные валюты», 2014. URL: https://eurasiangroup.org/files/ FATF_docs/Virtualnye_valyuty_FATF_2014.pdf (дата звернення: 06.11.2019).

5. Virtualcurrencyschemes-afurtheranalysis.EuropeanCentralBank.URL:https://ec.europa. $\mathrm{eu} /$ transparency/regexpert/index.cfm?do=groupDetail.groupDetailDoc\&id $=30639 \&$ no $=5 \quad$ (дата звернення: 06.11.2019).

6. Directive (EU) 2018/843 of the European Parliament and of the Council of 30 May 2018. EUR-Lex (Access to European Union law) : вебсайт. URL: https://eur-lex.europa.eu/legalcontent/EN/TXT/?uri=CELEX:32018L0843 (дата звернення: 06.11.2019).

7. David Chaum. Wikipedia : вебсайт. URL: https://en.wikipedia.org/wiki/David_Chaum (дата звернення: 06.11.2019).

8. Рыночная капитализация Bitcoin. Coin Market Cap : веб-сайт. URL: https://coinmarketcap.com/ru/currencies/bitcoin/ (дата звернення: 06.11.2019).

9. Погрібний Д. Питання визначення правового статусу криптовалют та господарсько-правового забезпечення їх використання в Україні. Теорія і практика правознавства : електронне наукове фахове видання. 2018. T. 2. № 14. URL: http://tlaw.nlu.edu.ua/ article/view/147796/148940 (дата звернення: 06.11.2019).

10. China Bans anti-blockchain sentiment as it prepares for launch of state cryptocurrency. The Independent. 2019. 30 October. URL: https://www.independent.co.uk/life-style/gadgetsand-tech/news/china-cryptocurrency-blockchain-bitcoin-a9176636.html (дата звернення: 06.11.2019).

11. Korea's Presidential Committee pushes to give cryptocurrency legal status. Decrypt : вебсайт. URL: https://decrypt.co/10891/korean-presidential-committee-pushes-to-givecryptocurrencies-legal-status (дата звернення: 06.11.2019).

12. Cryptocurrency in Japan: A Brief History. Scalex : вебсайт. URL: https://www.skalex. io/crypto-japan/ (дата звернення: 06.11.2019).

13. Guidance on Cryptoassets (Policy Statement PS19/22, July 2019). FCA : вебсайт. URL: https://www.fca.org.uk/publication/policy/ps19-22.pdf (дата звернення: 06.11.2019).

14. The Future of Cryptocurrencies in the UK Hangs on FCA's Decision. Cointelegraph : вебсайт. URL: https://cointelegraph.com/news/the-future-of-cryptocurrencies-in-the-uk-hangs-onfcas-decision (дата звернення: 06.11.2019).

15. Поливка Н. Криптовалюти і «різноманітні біткоіни». Юридична газета Online. 2015. № 22-23 (468-469). URL: http://yur-gazeta.com/publications/practice/informaciyne-pravotelekomunikaciyi/kriptovalyuti-i-riznomanitni-bitkoini.html (дата звернення: 06.11.2019).

16. UAEAccepts Cryptoregulation, Blockchain Projects Stand to Benefit. Cointelegraph : вебсайт. URL: https://cointelegraph.com/news/uae-accepts-crypto-regulation-blockchain-projectsstand-to-benefit (дата звернення: 06.11.2019).

17.Оприлюднено концепцію державної політики у сфері віртуальних активів. BRDO (Офіс ефективного регулювання) : вебсайт. URL: https://brdo.com.ua/news/uhvalenokontseptsiyu-derzhavnoyi-polityky-u-sferi-virtualnyh-aktyviv/ (дата звернення: 06.11.2019).

18. Роз'яснення НБУ щодо правомірності використання в Україні «віртуальної валюти/криптовалюти» Bitcoin. URL: https://zakon.rada.gov.ua/laws/show/n0435500-14 (дата звернення: 06.11.2019).

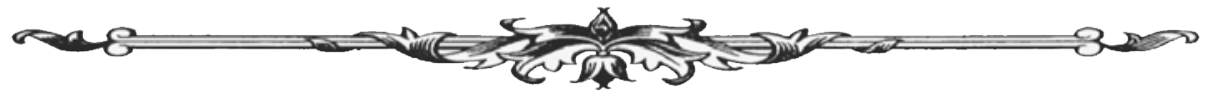


19.Cashless economy. Національний банк Украӥни : вебсайт. URL: https://bank.gov.ua/ doccatalog/document?id=30432161 (дата звернення: 06.11.2019).

20.Спільна заява фінансових регуляторів щодо статусу криптовалют в Україні. URL: https://bank.gov.ua/control/uk/publish/article?art_id=59735329 (дата звернення: 06.11.2019).

21.Мінцифри хоче легалізувати в Україні майнінг криптовалют. УНІАН : вебсайт. URL: https:/www.unian.ua/economics/finance/10711770-mincifri-hoche-legalizuvati-v-ukrajinimayning-kriptovalyut.html (дата звернення: 06.11.2019).

22. Про схвалення Концепції державної політики у сфері віртуальних активів : проєкт розпорядження Кабінету Міністрів України (неофіційний текст). URL: https://ips.ligazakon. net/document/view/nt4372?an=2 (дата звернення: 06.11.2019).

23.Про обіг криптовалюти в Україні : проєкт закону України від 6 жостня 2017 р. № 7183. URL: http://w1.c1.rada.gov.ua/pls/zweb2/webproc4_1?pf3511=62684 (дата звернення: 06.11.2019).

24.Про стимулювання ринку криптовалют та їх похідних в Україні : проєкт закону України від 10 жовтня 2017 р. № 7183-1. URL: http://w1.c1.rada.gov.ua/pls/ zweb2/webproc4_1?pf3511=62710 (дата звернення: 06.11.2011).

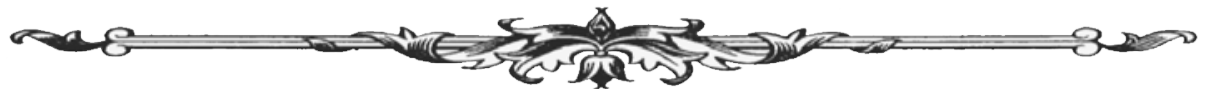

